\title{
光学ガラスの押し込みかたさ
}

\author{
鈴 木 勲・泉 谷 徹 郎 \\ ((株) 保谷硝子 技術研究所)
}

\section{Indentation Hardness of Optical Glass}

\author{
By \\ Isao SUZUKI and Tetsuro IZÚMITANI \\ (Hoya Glass Works Ltd.)
}

This investigation was made to clarify how the indentation hardness of optical glass depends upon the effect of densification or plastic flow.

To examine the effect densification has upon indentation hardness, optical glasses with Knoop indentations were heat-treated at temperatures below their transition temperature. After heat-treatment, the percentage of change in the longer diagonal length of Knoop indentations was measured. These experiments were carried out on fused silica, BK, K, $\mathrm{KF}, \mathrm{F}, \mathrm{SF}, \mathrm{SK}, \mathrm{SSK}, \mathrm{BaF}$ and $\mathrm{BaSF}$ glasses. Indentation recovery was found to be very small in optical glasses. Further, it was found that SF glasses which have the largest indentations show little or no change, while BK glasses which have small indentations show a much greater percentage of change. These results show that indentations in optical glasses are not always related to densification.

Using an interference microscope, Knoop indentation perimeters were observed in BK, KF, LLF, LF, F, SF, SK and SSK glasses. Without exception, a hump was found to be formed entirely around each indentation. This humping phenomenon shows that plastic flow occurs during indentation. Moreover, it was found that the ratio of the width $\left(c^{\prime}\right)$ of the hump around the shorter diagonal to the shorter diagonal length $\left(a^{\prime}\right)$ is approximately proportional to $c / a$ calculated from Hill's theory on plastic-elastic materials, where (a) is the spherical radius of the cavity generated by a pressure and $(c)$ is the spherical radius of the plastic region around the cavity. This means that Hill's theory can be applied to the indentation phenomenon of optical glass and accordingly the indentation of optical glass is always related to plastic flow.

The relationship between Young's modulus and glass composition was found to be almost parallel to the relationship between Knoop hardness and glass composition. Both Knoop hardness and Young's modulus increased with the content of net-work former. This supports Hill's theory. It was also found that $c / a$ decreases with the content of glass network former.

From these experimental results, it would be concluded that the indentation hardness of optical glass, which contains a large amount of net-work modifier, is far more an expression of resistivity to plastic flow than densification.

[Received March 8, 1972]

\section{1. 緒言}

微小押し込みかたさは，比較的簡単に測定できる材料 の物性值の 1 つで，その実用的な意味の他に，ガラスの 構造および機械的性質に関する情報を得る重要な手段と しても用いられてきだ.

しかしながら，ガラスでは，圧子の押し込みによる変 形過程・機構は，まだ充分には明らかにされて招らず， 圧子の押し込みによる圧痕の形成が，ガラスのどのよう な性質に基づくものか，どのような性質を意味するもの
か明らかにされていない，この圧子の押し込みによる圧 痕の形成に関しては, 従来, 主な説として, それが材料の densification によるものとする説 ${ }^{2(4)}$ と, ガラスの microplasticity と結びつけ，材料の plastic flowによるも のとする説がある(5) 7). 例えば, Neely, Mackenzie ${ }^{3}$ は， 石英ガラスについて, 転移点以下の温度でビッカース圧 痕を熱処理し，その時に圧痕の大きさが減少する。つま り回復するということから，圧子の䄨し込みによって形 成された圧痕部分は密度が増大して抢り，したがって石 


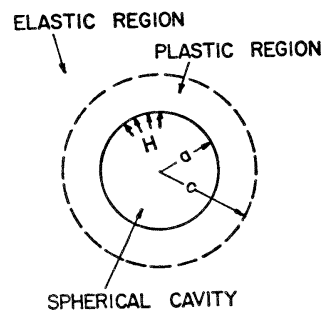

Fig. 1. Spherical shell model of Hill's theory on plastic-elastic material.

英ガラスの押し込み圧痕は, 材料の densification によ って形成され，その押し込みかたさ值は，材料の densification に対する抵抗として定義すべきであるとしてい る.

一方 $\mathrm{Marsh}^{6), 7)}$ は, 従来から知られているガラスの microplastic な挙動を示唆する実駼結果 ${ }^{6}$ から, 押し込 み圧痕は, ガラスの塑性変形によるものとし, 押し込み かたさ值からガラスの降伏応力を計算し, 強度との関係 を論じた、すなわち，金属などの押し込みかたさは，通 常, 塑性理論で解釈されているが，Marsh は，ガラスは 金属に比べてヤング率が低く，一方その降伏応力は高い 材料と考えら孔るので, 押し込み過程での材料の弾性変 形む考慮に入れ, Hill の弾塑性体に対する球款の理論8) 老修正して降伏応力を求姉た。 その結果, この降伏応力 と flawless glass fiber の強度がよく一致すると報告し ている.

Hill によれば，均一な無限の拡がりをもった材料中 氾，図-1 に示したような空洞になった球を考え，その 内部から一様な圧力をかけて球殼を押し拡げた場合に， 球款の半径が 0 から $a$ に押し拡げられたときの圧力を $H$, その時に球殼の外側に形成される塑性領域の端まで をcとすると, 次の関係が求的られる.

$$
\begin{aligned}
& \left(\frac{c}{a}\right)^{3}=\frac{E}{3(1-\nu) Y} \cdots \cdots . . . \\
& H=\frac{2}{3} Y\left\{1+3 \ln \left(\frac{c}{a}\right)\right\}
\end{aligned}
$$

ただし，E はヤング率，ンはポアソン比，Y $Y$ は降伏応 力である.Hを押し込みかたさと考えると, Hill の理 論では (2) 式に示されたように，かたさは，材料の降伏 応力が高いほど，また押し込々量（a）に対する塑性変 形領域の拡がり (c) の度合を示す $c / a$ が大きいほど, 大きな值を示す。また $c / a$ は，(1) 式に示されるよう に，ヤング率と降伏応力によって決定されるので，結局 かたさは降伏応力とヤング率の関数であり, 降伏灾力, ヤング率の高いほど大きな值を示す.

本研究では, 種々の光学ガラスについて, 押し込み圧 痕の熱処理による回復の度合を測定し，また圧子の押し 込みによる圧痕周辺部の「盛り上り」の有無を干渉顕微 鏡で観察し，実際に使用されている光学ガラスで材料の densification 㧍よび plastic flow が，押し込み圧痕の 形成にどのように寄与しているのかを明らかにすること を目的とした. 更に，弾塑性体に対する Hill の理論を 光学ガラスの押し込みかたさに適用できるかどらかを検 討し, 光学ガラスの押し込みかたさと物性の関係をより 明確にすることを試みた。 またガラス組成の面からも押 し込みかたさを検討してみた。

\section{1 押し込み圧痕の作成}

\section{2. 実 験 方 法}

当社で製造されている光学ガラスのブロックから適当 な大きさに切り出し, 研磨して, 厚さ $10 \mathrm{~mm}$ 前後に仕 上げたガラスプレートを試料に用いた。 圧痕の作成に は，自動負荷微小硬度計（島津製作所製 NT-M 001） を用い，室温で，ヌープ圧子を研磨された試料の測定面 に 100 1000 g の荷重で押し込み, 圧痕を作成した。負 荷時間は 15 秒である. 圧子に対稜角が $172^{\circ} 30^{\prime}$ と $130^{\circ}$ のダイヤモンド四角錐であるヌープ圧子を用いたのは， 通常の方法で研磨された試料の場合, ビッカース圧子で は $50 \mathrm{~g}$ 程度の荷重でも圧痕からクラックが発生し, ク ラックを伴なわない圧痕を得ることがかなり困難である の化対し，ヌープ圧子では，比較的高い荷重まで，クラ ックを伴なわない压痕を容易に得ることができるためで ある。得られた圧痕の大きさとして, 硬度計付属の金属 顕微鏡を用いて 400 倍でヌープ圧痕の長い方の対角線長 さを測定した。測定は, 各試料で, 7 個の圧痕について 行ない, その平均值を圧痕の大きさとした。各測定值の 平均值に対するばらつきは，上1％程度である。

また，ヌープかたさ值は，圧痕を作成したときの荷重 を, この圧痕の長い方の対角線の長さから求めた圧痕の 投射面積で除した商（つまり平均圧力）で表わされ，次 式より求められる。

$$
\begin{aligned}
\text { ヌープかたさ } & =\frac{P}{\frac{1}{2} \cdot \cot \left\{\frac{1}{2}\left(172^{\circ} 30^{\prime}\right)\right\} \cdot \tan \left\{\frac{1}{2}\left(130^{\circ}\right)\right\} d^{2}} \\
& =14.23 \frac{P}{d^{2}}\left(\mathrm{~kg} / \mathrm{mm}^{2}\right) \quad \cdots \ldots \ldots \ldots \ldots(3)
\end{aligned}
$$

ただし， $P$ は荷重 $(\mathrm{kg}), d$ は長い方の対角線長さ $(\mathrm{mm})$ である。

\section{2 圧痕の熱処理}

圧痕の作成された試料を, 所定の熱処理温度の電気炉 中で 2 時間熱処理し，その後，2.1 で述べたのと同様に 400 倍の金属顕微鏡でヌープ圧痕の長い方の対角線の長 さを測定し，熱処理による圧痕の大きさの変化を求め た.

\section{3 圧痕の干渉顕微鏡観察}

圧子の押し込みに上り形成された圧痕並びに圧痕周辺 部の形状を求めるために, 反射干涉顕微鏡（Leitz， Wetzlar）を用いて 500 倍の倍率で，ヌープ圧痕を観察 


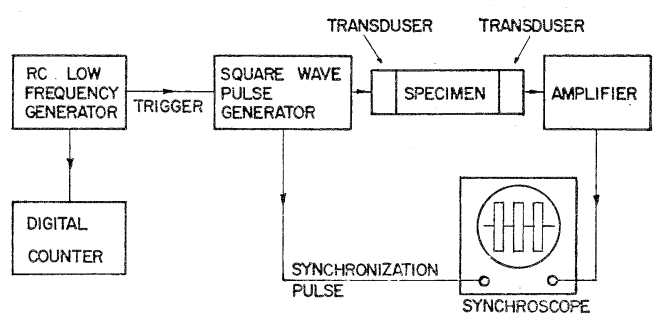

Fig. 2. Block diagram of apparatus for measuring Young's modulus ${ }^{9)}$.

した。光源はタングステンランプで， $546 \mathrm{~m} \mu$ の干渉フ イルターを使用した。

\section{4 ヤング率の測定}

弾塑性体に対する Hill の球壳理論によると, 押し达み かたさは降伏応力とヤング率の関数として表わされるの で，光学ガラスのヤング率を測定した。ヤング率・ポア ソン比は，パルス重畳法 ${ }^{9}$ でガラス中の縦波および横波 の音速を測定し，(4)〜 (6) 式の関係を用いて算出した。

$$
\begin{aligned}
& v_{s}=\sqrt{\frac{G}{\rho}} \ldots \ldots \ldots \ldots \\
& v_{l}=\sqrt{\frac{G}{\rho} \cdot \frac{4 G-E}{3 G-E}} \\
& \nu=\frac{E}{2 G}-1 \quad \ldots \ldots \ldots
\end{aligned}
$$

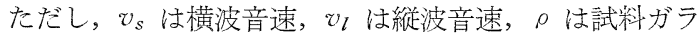
スの密度，E はヤング率，G は岡性率，レはポアソン 比である。

測定装置のブロックダイヤグラムを図-2 に示した。 変換子には，縦波には $X$ 一カット，横波には Y-カット の水晶を用いた. この変換子の共振周波数は $5 \mathrm{MHz}$ で ある・

$25 \times 20 \times 100 \mathrm{~mm}$ と $25 \times 20 \times 70 \mathrm{~mm}$ の 2 種類の大き さの試料を用いて測定し，その平均值から縦波执よび横 波の音速を求めた。このヤング率の測定に伴なら誤差は 1\%以内である。

\section{3. 䒠 験 結 果}

\section{1 圧痕の熱処理}

Mackenzie らが石英ガラスのビッカース圧痕について 行ったのと同様に, 石英ガラスおよび $\mathrm{SiO}_{2}-\mathrm{B}_{2} \mathrm{O}_{3}-\mathrm{R}_{2} \mathrm{O}-$ (RO) 系の $\mathrm{BK}, \mathrm{SiO}_{2}-\mathrm{R}_{2} \mathrm{O}-\mathrm{PbO}$ 系の $\mathrm{KF} \cdot \mathrm{F} \cdot \mathrm{SF}, \mathrm{SiO}_{2}-$ $\mathrm{B}_{2} \mathrm{O}_{3}-\mathrm{BaO}$ 系の $\mathrm{SK} \cdot \mathrm{SSK} \cdot \mathrm{BaF} \cdot \mathrm{BaSF}$ などの種々の光学 ガラスについて, ヌープ圧痕の熱処理による回復を測定 した. 図-3 は, 荷重 $200 \mathrm{~g}$, 負荷時間 15 秒の条件で作成 したヌープ圧痕を各試料ガラスの転移点以下の各温度で 2 時間保持し熱処理したときの圧痕の回復の度合を示し たものである.光学ガラスでは,各ガラスの転移点近傍ま で処理した．熱処理による痕の回復は処理温度の上昇 をともに大きくなり，石英ガラスの圧痕は, Mackenzie

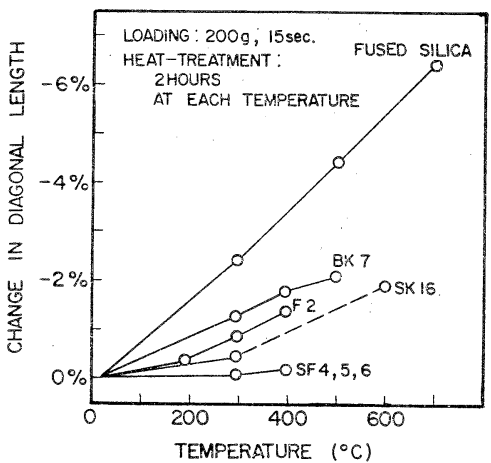

Fig. 3. Change in the longer diagonal length of Knoop indentation by heat-treatment.

らの測定結果とほぼ同程度の回復の度合を示した。しか し，光学ガラスでは，熱処理による圧痕の回復が，一般 に石英ガラスのそれに比べてずっと少なく，最も大きな 回復の度合を示した BK 7 でも $500^{\circ} \mathrm{C}$ での熱処理後で $2 \%$ 程度の回復を示したにすぎない，BK系のガラスは， $\mathrm{SiO}_{2}-\mathrm{B}_{2} \mathrm{O}_{3}-\mathrm{R}_{2} \mathrm{O}-(\mathrm{RO})$ 系からなり, 光学ガラス中では, 網目形成酸化物 (特に $\mathrm{SiO}_{2}$ ) の含有量の最む多い部類 に属するガラスである. また更に, $\mathrm{PbO}$ を多量に含有 した SF 系のガラスでは, 熱処理による圧痕の回復がほ とんど認められなかった。

図-4 は, 荷重 $100 \mathrm{~g}$ で各硝種に作成したヌープ圧痕 を，400 C で 2 時間熱処理したときのヌープ㽵痕の回復 の度合と処理前の圧痕の大きさの関係を示したものであ る.図-4 は，圧痕の大きな SF ガラスがかえって圧痕 の回復が少なく，逆に，圧痕の小さい BKガラスがかえ って大きな圧痕の回復のあることを示しており，圧痕の 大きさが圧痕の回復, つまり densification 量に比例し ないことを示している．なお， SF 系のガラスの転移 点は, $425^{\circ} \sim 435^{\circ} \mathrm{C}, \mathrm{BK}$ 系のガラスの転移点は $550^{\circ} \sim$ $555^{\circ} \mathrm{C}$ で，図 -4 は， $\mathrm{SF}$ 系のガラスの転移点付近で熱処

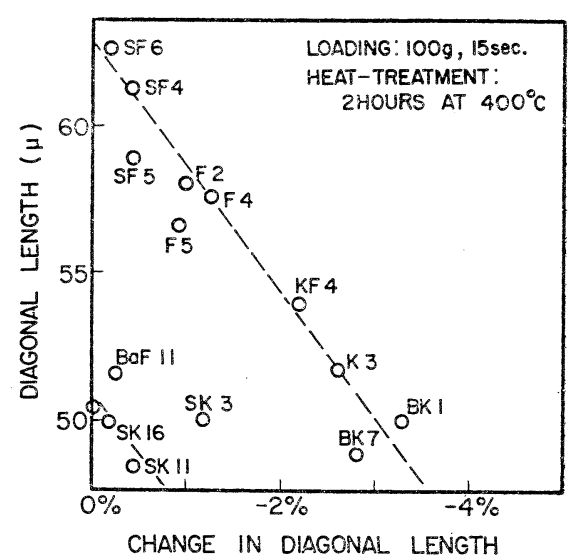

Fig. 4. Relationship between diagonal length of Knoop indentation and the percentage of change by heat-treatment. 


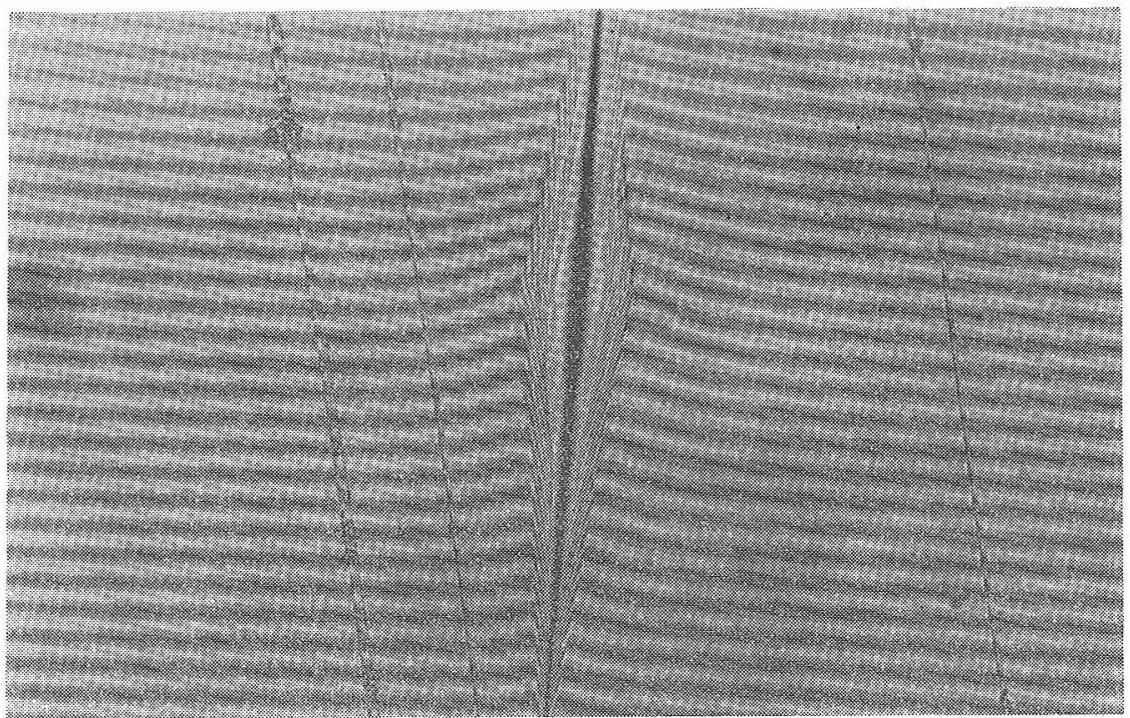

Fig. 5. Interferogram of a hump around indentation perimeter in SF 5 glass. $(\times 500)$

理した結果を示したものである。

\section{2 圧痕の干啮顕微鏡観察}

種々の光学ガラ久のヌープ压痕に「盛り上り」が存在 するかどらかを確かめるために，ヌープ圧痕並びに压痕 周辺部の形状を反射干渉顕微鏡で観察した。

図-5 はその 1 例で，荷重 $1 \mathrm{~kg}$, 負荷時閒 15 秒の条 件で SF 5 亿作成したヌープ圧痕の干涉影微鏡写真で亦 る. 圧痕の周辺部で明膫な干渉縞の変化が認められる。 しかも周辺部の干涉縞が圧痕内部に扔ける干渉縞と逆の 方向に变化していることから，この圧痕周辺部分が盛り 上っていることがわかる．この干渉顕微鏡写真から压痕 中央部 (短い方の対角線上) での横断面の形状を求为た のが 図-6である。圧痕の染さ $3.3 \mu$ に対し,「盛り上 り」の高さは $0.3 \mu$ ，また「盛り上り」領域は左右で 85 ル飞も及んでいる。この盛り上り領域は，ほぼ一様に刘 称に形成されている. SK 系のガラス拉よび 3.1 の熱処 理実験で比較的大きな圧痕の回復を示した BK ガラスな どでも同様に明瞭な盛り上りが観察された。荷重 $500 \mathrm{~g}$, 負荷時閒 15 秒の条件で各硝種に作成されたヌープ圧渡 の干涉顕䘗鏡写真 (350 倍) から，短い方の対角線方向 に扔ける盛り上り領域の幅を，投影機（日本光学製，10 倍）により拡大し，ノギスで測定した。同様に，圧痕の

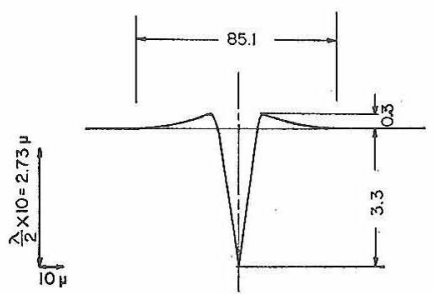

Fig. 6. Shorter diagonal cross section profile of Knoop indentation.
横幅（短い方の対角線長さ）と長い方の対伤線長さ学測 定し，その結果を表-1にまとめた。ただし，压痕の短 い方の詨角線長さ $a_{0}$, 盛り上り領域の幅 $c_{0}$ は, 上記の緑 にして測定された值であり，これらは，圧子がガラス面 から除去され，圧痕が弾性回復した後の各々の大きさを 示すものである．圧子の押し込み中でのこれらの值(そ れぞれ $a^{\prime}, c^{\prime}$ ) 正確に測定することは困難であるが， 弾性回復が少ないとされている長い方の対角線長さと圧 子の形状から圧痕の短い方の対角線方向に扔ける弹性回 復量を求め, 実測值 $a_{0}, c_{0}$ を補正して, 圧子の押し込み 中での痕の短い方の対角線長さ。盛り上り領域の幅を 推定した。すなわち，圧痕部分は，圧子が押し込まれて いる間は，圧子の形状にならうものとして， $a^{\prime}$ をヌー プ压子の幾何学的形状から長い方の対角線長さを用いて

Table 1. Width of the hump around shorter diagonal and shorter diagonal length of Knoop indentation made under a load of $500 \mathrm{~g}$ for a $15 \mathrm{sec}$ duration.

\begin{tabular}{lrcrrrr}
\hline \multirow{2}{*}{ Glass Type } & \multicolumn{3}{c}{ Indentation } & \multicolumn{2}{c}{ Hump } \\
\cline { 2 - 4 } & $\overbrace{l(\mu)}$ & $a_{0}(\mu)$ & $a^{\prime}(\mu)$ & & $c_{0}(\mu)$ & $c^{\prime}(\mu)$ \\
\hline BK 7 & 117.5 & 12.4 & 16.5 & 47.6 & 51.7 \\
KF 4 & 128.0 & 13.5 & 18.0 & 51.5 & 55.0 \\
LLF 1 & 129.6 & 14.1 & 18.2 & 45.8 & 49.9 \\
LF 6 & 132.5 & 14.2 & 18.6 & 48.0 & 52.4 \\
F 4 & 136.3 & 14.8 & 19.2 & 60.2 & 64.6 \\
SF 4 & 144.2 & 16.7 & 20.3 & 70.5 & 74.1 \\
SF 5 & 139.9 & 15.5 & 19.7 & 66.1 & 70.3 \\
SF 6 & 145.9 & 17.4 & 20.5 & 80.7 & 83.9 \\
SSK 1 & 119.0 & 14.0 & 16.7 & 62.9 & 65.6 \\
\hline
\end{tabular}

$l$ : observed longer diagonal length

$a_{0}:$ observed shorter diagonal length

$a^{\prime}$ : calculated shorter diagonal length value from $l$

$c_{0}$ : observed width of the hump around shorter diagonal

$c^{\prime}$ : calculated value of the hump width around shorter diagonal from $c^{\prime}=c_{0}+\left(a^{\prime}-a_{0}\right)$ 
計算で求めた。 また $c^{\prime}$ は, $c^{\prime}=c_{0}+\left(a^{\prime}-a_{0}\right)$ として補 正した。

\section{3 押し込みかたさと Hill の球殻理論}

弾塑性体における Hill の球殼理論 (1)，(2) 式から， 降伏応力 $Y$ 索消去すると次式が求められる.

$$
H=\frac{2}{9} \cdot \frac{E}{1-\nu} \cdot \frac{1+\ln \left(\frac{c}{a}\right)}{\left(\frac{c}{a}\right)^{3}} .
$$

（7）において，圧力 $H$ を押し込みかたさ值と考える と, この (7) 式から，各材料の $c / a$ 值が，押し込みか たさ值, ヤング率拉よ゙ホホアアンン比から計算で求めるこ とができる。

図-7は，パルス重畳法で測定したヤング率・ポアソ ン比および荷重 $100 \mathrm{~g}$ 負荷時間 15 秒の条件で測定した ヌープかをさ值を用いて（7）式から算出した $c / a$ と， 表-1 に示された, 除荷による圧痕の弾性回復量を考慮 し補正された盛り上り領域の幅 $c^{\prime}$ と圧痕の横幅（邓プ在痕の短い方の対角線長さ） $a^{\prime}$ の比 $c^{\prime} / a^{\prime}$ との関係を 示したものである. 図-7 から, Hill の理論から計算で 求められた $c / a$ の值と実測された $c^{\prime} / a^{\prime}$ の值はほぼ比例 していることがわかる。すなわち，分極性に富む $\mathrm{PbO}$

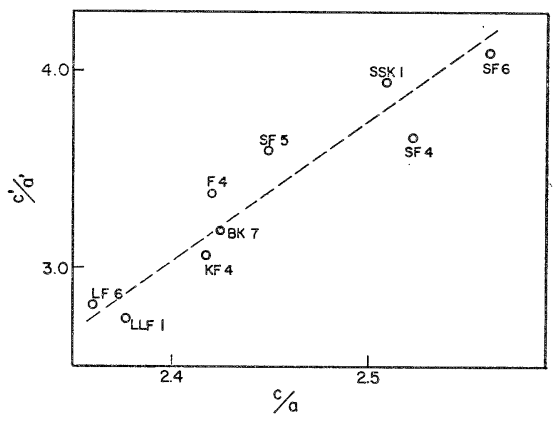

Fig. 7. Comparison of the calculated value of $c / a$ from Hill's theory, with the observed value of $c^{\prime} / a^{\prime}$ from the hump width and diagonal length of Knoop indentation.

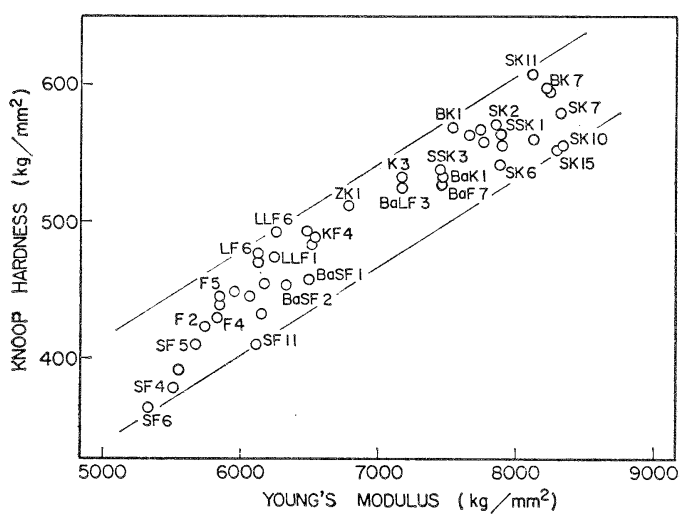

Fig. 8. Relationship between Knoop hardness and Young's modulus.
を多量に含有した SF 6 などのように，大きな盛り上り 領域を示し，圧痕の大きさに対する盛り上り領域の大き なガラスでは, 計算值 $c / a$ の值が大きくなり, また計算 值 $c / a$ の值の小さな $\mathrm{BK} 7$ などでは, やはり, 盛り上 り領域も小さく, 実測值 $c^{\prime} / a^{\prime}$ が小さくなっている，た だ，図-7 において， $c^{\prime} / a^{\prime}$ と $c / a$ に $1: 1$ の対応がない のは, Hill の理論が，球殼に対して誘導されたもので あるのに対し，実験では菱形のヌープ圧子が用いられた ことによるものであろう。

また，(7) 式では，押し込みかたさは，ヤング率と $c / a$ の関数で, ヤング率に比例している. 図-8 は, 光 学ガラスのヌープかたさとヤング率の関係を示したもの である、ヌープかたさは，ヤング率の高いガラスほど高 くなっており，ある幅をもってはいるが，両者が比例し ていることがわかる．同図におけるこの幅，つまりヤン グ率が同一でも, ヌープかたさの暴なるガラスが存在す るのは，硝種によって cla が異なるためであるう。

\section{4 押し込みかたさとガラス組成}

図-9 に，ガラス組成中の $\mathrm{SiO}_{2}, \mathrm{~B}_{2} \mathrm{O}_{3}$ などの網目形成 酸化物の含有量 (cationic\%) とヌープかたさの関係を, ガラスを構成する成分から光学ガラスを分類したガラス 系列(1)に従って整理して示した。 すなわち, 図-9 中の 各ガラス系列は，ほぼ同一の種類の成分から構成されて おり，例えば， $\mathrm{KF}-\mathrm{SF}$ 系は， $\mathrm{SiO}_{2}-\mathrm{R}_{2} \mathrm{O}-\mathrm{PbO}$ 系のガラ スであり, $\mathrm{SK}-\mathrm{BaSF}$ 系は, $\mathrm{SiO}_{2}-\mathrm{B}_{2} \mathrm{O}_{3}-\mathrm{BaO}$ 系のガラ スである、このようなガラス系列に従って両者の関係を 検討してみると，各ガラス系列内では，両者の関係はか なり密接で, 網目形成イオンの含有量の増加と共に, 押 し込みかたさが高くなっている。また，各ガラス系列閒

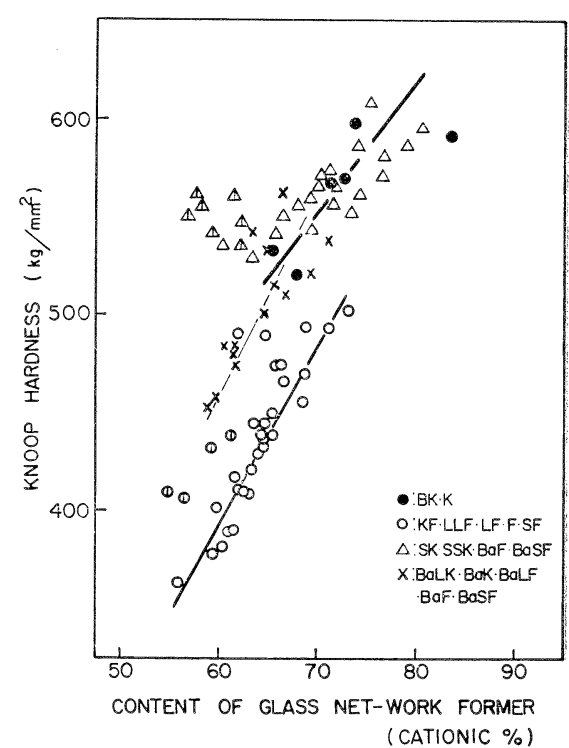

Fig. 9. Relationship between Knoop hardness and glass net-work former content. 


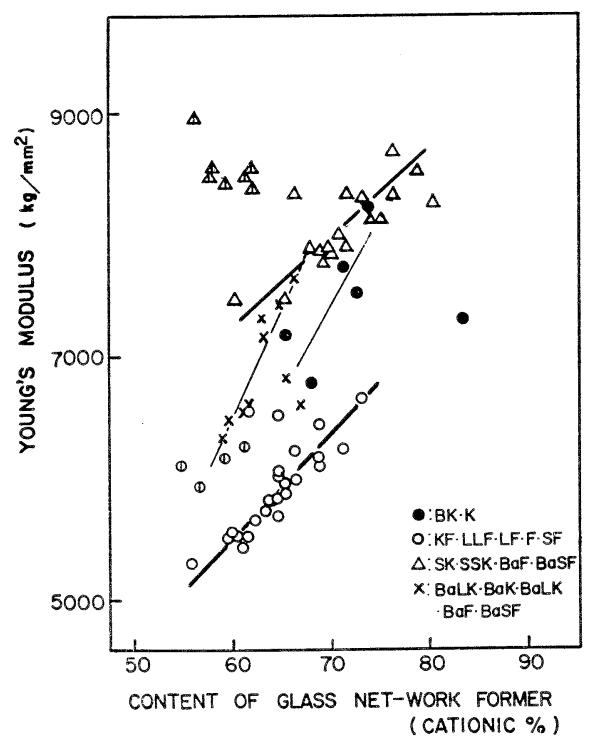

Fig. 10. Relationship between Young's modulus and net-work former content.

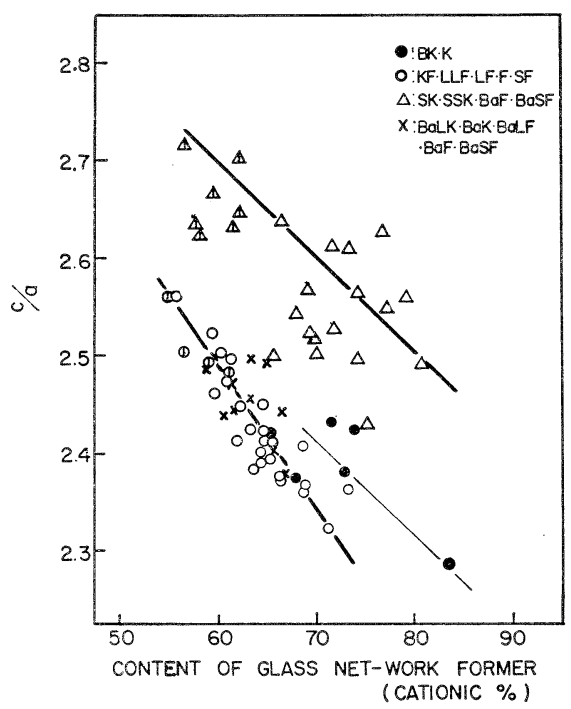

Fig. 11. Relationship between $c / a$ and glass net-work former content.

では，網目形成イオンの含有量が同一でもヌープかたさ に差が認められるが，これは，ヌープかたさが修飾酸化 物の種類によって副次的に影響されることを示してい る、修飾酸化物として，主として $\mathrm{BaO}$ を含有している $\mathrm{SK}-\mathrm{BaSF}$ 系の方が，分極性に富む $\mathrm{PbO}$ を含有する KF-SF 系よりヌープかたさが高くなっている.

Hill の理論から導いた（7）式では，押し込みかたさ は，ヤング率と $c / a$ の関数であるが, 図-10 は, ヤング 率と網目形成イオンの含有量 (cationic\%) の関係を示 したものである.ヤング率もヌープかたさと同様に，網 目形成イオンの含有量に支配され, 網目形成イオンの含
有量の増加と共に高くなっている．またこの場合も，修 飾酸化物の種類によってヤング率が影響され，ガラス系 列間に差が認められる。図-11 には，(7) 式から計算で 求めた $c / a$ と網目形成イオンの含有量 (cationic\%) の 関係を示した. $c / a$ は, 網目形成イオンの含有量が増加 すると減少しており，また網目形成酸化物として $\mathrm{B}_{2} \mathrm{O}_{3}$ を比較的多量に含有している $\mathrm{SK}-\mathrm{BaSF}$ 系は $c / a$ が大 きくなっている.

\section{4. 考察}

\section{1 densification と押し込みかたさ}

densification が光学ガラスの庄痕の形成に寄与する度 合を，圧痕の熱処理による回復の度合から検討した。図 -2 , 図-3 に示したよらに, 網目形成酸化物, 特に $\mathrm{SiO}_{2}$ の含有量の多いBK ガラスなどでは, 熱処理による痕 の回復の度合が，他の光学ガラスに比べて比較的大きな 值を示しているが，石英ガラスに比べるとずっと少なく (約 $2 \%)$, これらのガラスでも圧痕の形成にdensification が寄与する度合はごくわずかであると考えられる。 た，熱処理によってほとんど圧痕の回復を示さない SF ガラスなどは, 圧痕の形成に densification がほとんど 寄与していないと思われる.

また更に，図-3 に示されたような，SF ガラスのよう に大きな圧痕の形成されるガラスで熱処理による圧痕の 回復がほとんどなく, 逆により小さな圧痕の形成される BK ガラスの方がより大きな回復の度合を示すといら実 験結果は，光学ガラスの押し込み圧痕が材料の densification だけで形成されるとするのは困難であるという ことを示すものと考えられる。 もし，押し込み圧痕が材 料の densification だけによって形成されるとすれば, 転移点の低い SF ガラスの熱処理による回復の度合は, すくなくとも，転移点の高い BK ガラスの回復の度合と 同程度以上でなければならないと思われるからである。 したがって，以上の熱処理による実験結果は，一般に修 飾酸化物を多量に含有した光学ガラスの押し込みかたさ を材料の densification といらことだけで解釈すること はできないことを示したものであると考えられる。

\section{2 plastic flow と押し込みかたさ}

一般に, 光学ガラスの押し込み圧痕に, 図-5に示し たよらな明瞭な盛り上りが認められたことは，圧子の押 し込みによってガラスが流動したことを示しており，圧 痕の形成にガラスの plastic flow が寄与していることを 直接示したものであると考えられる。したがって，光学 ガラスの押し込みかたさは，材料の densification より は，むしろ plastic flow に影響されていると考えられ る.

また図-7 は Hill の理論における球殼の大きさ (a) として押し込み圧痕の大きさ $\left(a^{\prime}\right)$ を，また塑性変形領 
域の拡がり (c) として圧痕に形成される盛り上り領域の 大きさ $\left(c^{\prime}\right)$ をとり，弾塑性体を前提とした Hill の球 殸理論がガラスの押し込みかたさに適用できるかどうか を検討したものである. Hill の理論では，空球を一様 な圧力で押し拡げ，応力・歪分布が，空球の中心からの 距離だけの関数になり, 一様に球状に分布しているとし ており，ヌープ圧子のような形状の圧子で押し込んだ場 合に，このような仮定で Hill の理論をそのまま用いる のは多少無理があるかも知れないが，図-7 に示された ように, Hill の式から計算で求めた $c / a$ とヌープ不痕 に形成された盛り上り領域に基づく $c^{\prime} / a^{\prime}$ がほぼ対応し ているので，少なくとも定性的には，Hill の理論が光 学ガラスの押し込みかたさに適用できると考えられる。 同図に蛙いて勾配が 1 になっていないが，これは圧子の 形状によるものであるら。また図-8に示されるように， ヌープかたさとヤング率に比例関係のあることも Hill の理論から理解される。したがって, 光学ガラスの押し 込みかたさは，弾塑性体にお打る塑性流動によるもので あり，降伏応力とヤング率の関数として表わされる。

次にヌープかたさ・ヤング率並びに $c / a$ とガラス組成 の関係を検討した結果，まずヌープかたさとヤング率 は, 図-9, 図-10 に示されたように, 修飾イオンの種類 に影響されているけれども，共に網目形成イオンの含有 量に支配されており, 網目形成イオンの含有量の増加と 共に高くなっている。しかも, 図-9 と図-10 は, 全く 同一ではないが，よく類似している。この結果は，Hill の (7) 式から予想される結果と対応するすので, 図 -9 と 図-10 の差は，ガラスのヌープかたさがヤング率の他に claにも影響されることを示すものであると考えられる。 この $c / a$ は, 図-11 に示したよらに, 網目形成イオンの 含有量の増加とともに減少しているが, このことは, 流 動性の減少, 降伏応力の増大を意味し, したがって, 網 目形成イオンの含有量が増加すると plastic flow しにく くなることを示していると考えられる，つまり，ガラス 構造中に修飾イオンが導入され，網目構造が切断される ほどガラスが流動しやすくなるということは，当然考え られることである。したがって，これら，ヌープかたさ， ヤング率および $c / a$ と網目形成イオンの含有量の関係 （図-9〜11）は，押し込みかたさを Hill の球款理論に 基ういて解釈することの妥当性,つまり, 材料の microplasticity に基づいて解釈することの妥当性を示したも のであると考えられる。

\section{5. 総括および結 論}

光学ガラスの押し込み圧痕がガラスの densification によるものなのか，または， plastic flow によるものな のかを明らかにするために，ヌープ圧痕の熱処理による 回復量を測定し，干涉顕微鏡によってヌープ圧痕・圧痕
周辺部の形状を観察した. また更に, 光学ガラスの押し 込みかたさに, 弾塑性体に対する Hill の球款理論を適 用することの可否孛検討した。そその結果次のことがわか った.

（1）光学ガラスでは，一般に熱処理による㾏痕の回 復が非常に少なく，特に SF ガラスでは，大きな圧痕が 形成されるにもかかわらず，熱処理に上る压痕の回復は ほとんどない。

（2）一般に，光学ガラスの圧痕图辺部には，明瞭な 「盛り上り」が浔められる。

（3）この圧子の押し込みによって㾏痕周辺部に形成 された盛り上り領域の広さ $\left(c^{\prime}\right)$ と庄痖の大きさ $\left(a^{\prime}\right)$ の 比は，弾塑性体に対する Hill の理論办ら蔀びかれた $c / a$ とほぼ対応し，Hill の理論吕光学ガラスの押し込みか たさに適用できること示した。

（4） ヌープかたさは，ガラスを構成する成分中の網 目形成イオンの含有量に支配され，網目形成イオンの含 有量の増加と共に高くなる。京た修飾イオンの種類に副 次的に影響される. Hill の理論から，押し込みかたさ は，ヤング率と $c / a$ の関数としても表現できるが，ヤン グ率と網目形成イオンの含有量の関係は, ヌープかたさ と網目形成イオンの含有量の関係によく詨忘しており, また $c / a$ は, 網目形成イオンの含有量の増加と共に減少 し, 降伏応力の増大, 流動性の減少と関倸していること 定示した。

したがって, 光学ガラスの押し込多圧痕は, ガラスの densification よりはむしろ plastic flow によって形成 され，また押し込みかたさには，弾塑性体に対する Hill の球款の理論が適用でき, その理論に従って, 押し込み かたさはヤング率と降伏応力によって決定されると考え られる。

\section{文献}

1) L. Ainsworth, J. Soc. Glass Technol. 38, 479 $\mathrm{T}^{-547_{\mathrm{T}}}$ (1954).

2) W.B. Hillig, "Advances in Glass Technology" Plenum Publishing Corp., New York (1963) Part 2 p.p. 51-52.

3) J.E. Neely and J.O. Mackenzie, J. Materials Science 3 [6] 603-09 (1968).

4) F.M. Ernsberger, J. Am. Ceram. Soc. 51 [10] 54547 (1968).

5) E.W. Taylor, J. Soc. Glass Technol. $3469_{\mathrm{T}}-76_{\mathrm{T}}$ (1950).

6) D.M. Marsh, Proc. Roy. Soc. A 279, 420-35 (1961).

7) ibid, A 282, 33-43 (1964).

8) R. Hill, "The Mathematical Theory of Plasticity" Oxford University Press (1950) p.p. 97-127.

9) T. Inamura, Japan J. Appl. Phys. 6 [7] 802-07 (1967).

10）泉谷徹郎，“光学技術ハンドブック”朝倉畫店 p.p. 568 74.

(3/8/1972 受付) 